\title{
An Empirical Study of the Impact of Corporate Governance on R\&D Investment Expenditure Based on Guangdong High-tech Enterprises
}

\author{
Pengyi YU, Ruixian LI, Shuting FANG \\ School of Accounting. Guangdong University of Foreign Studies \\ Guangdong University of Foreign Studies, GDUFS \\ Guangzhou, China \\ e-mail: yxyy30@263.net
}

\begin{abstract}
R\&D investment has already become the strategic investment in the process of the growth and sustainable development of enterprises. The previous researches indicate that the $R \& D$ investment is affected by corporate governance. It is of significance to research on corporate governance improvement so as to solve the shortage of $R \& D$ investment. Based on various natures of different industries, the article make comprehensive exploration on the impacts upon $R \& D$ investment in terms of concentration degree of equity, the board size, the incentive of top management and debt rate. It concludes that the relationship between corporate governance and $R \& D$ investment differs in a significant way among different industries. It is essential to tailor the corporate governance to different industries so as to solve the shortage of R\&D investment.
\end{abstract}

Keywords-high-tech enterprise; corporate governance; $R \& D$ investment

\section{INTRODUCTION}

At present, the research on corporate governance and R\&D investment mainly focuses on the study of the relationship between corporate governance and $R \& D$ investment behavior. Scholars have studied the effect of the increase in ownership concentration on R\&D investment, they believe that the large shareholder has a larger stake in the company, in order to maintain the competitive advantage of enterprises, participation in corporate management decision-making has a clear initiative. Domestic research rarely concerns the impact of the industry characteristics on the corporate governance will lead to industry differences which influence R\&D investment while foreign studies mostly consider an industry as the main research objectives for empirical research. For this purpose, our paper will explore the industry characteristics and development rules that the Guangdong high-tech enterprises should follow in corporate governance through the empirical research on the relationship between corporate governance and corporate performance of them.

\section{THEORY AND HYPOTHESIS}

This paper will focus on the effect of Guangdong hightech enterprises on R\&D investment in the empirical study, based on previous literature, to analyze the correlation of corporate governance and investment behavior from the ownership structure of the enterprise, the size of the board, management incentives and asset-liability ratio. With regard to the effect of ownership concentration and level of R\&D investment, researchers hold three different views-positive correlation, negative correlation and irrelevance ${ }^{[5]}$. This paper argues that the benefits of the ultimate owner are more consistent with the size of the enterprise's technological input in the long term when the ultimate owner of the company has more equity, at the same time, the ultimate owner will be more motivated to promote the company's R\&D investment and technological innovation [1]. Therefore, ownership concentration enable the major shareholders to take the initiative to collect information on technological innovation of the industry, to supervise the innovation and R\&D activities of senior executives, so as to avoid internal control problem and free-riding behavior. Compared with the scale of investment, enterprises' high-tech investment in both the success rate of R \& D and technology products in the market prospects are highly uncertain. Once the investment fails, not only does the company suffer huge money losses, but will face the risk of loss of competition opportunities while the manager's position will more easier be replaced. In general, the lack of incentives for senior executives will lead to the lack of $\mathrm{R} \& \mathrm{D}$ investment and technological innovation enthusiasm from them. However, from the aspect of the major shareholders' interest and companies' strategies, they probably encourage senior executives to increase the $R \& D$ investment and technological innovation in order to enhance the core competitiveness of enterprises and fulfill consumers' needs. From the above point of view, we propose Hypothesis 1:

H1: The higher the concentration of ownership, the more the innovation investment of high-tech enterprises.

In theory, directors should perform their duties which is granted by the board of directors to supervise the management personnel as the company representative, and try to invest more fair and realistic views in decisionmaking. Hence, the expansion of the scale of the board of directors will enable professionals with different backgrounds, experiences and abilities to make constructive comments, which will reduce the risk of company investment in technological innovation and have a positive effect on $R \& D$ investment to some extent [2]. From the above point of view, we propose Hypothesis 2: 
H2: The larger the size of the board of directors, the greater the innovation investment in high-tech enterprises.

In reality, senior executives' shareholding is more often appeared in the high-tech enterprises, which is determined by the characteristics of themselves. First of all, high-tech enterprises are more inclined to perform that the establishment of a shorter business years, the size and strength is smaller than state-owned enterprises, both the founder and senior executives are young, higher educated, more easier to accept all kinds of incentives; Secondly, for the small or medium-sized high-tech enterprises which are established of a short time, stock ownership incentive costs are relatively low and do not need to pay in the current period, so that limited funds can be invested into high-tech research and promotion of its technology products, to face market competition better and maintain their competitive advantages. Some research showed a positive correlation between annual salary of senior executives and R\&D investment. From the above point of view, we propose Hypothesis 3:

H3: The higher the proportion of senior executives shareholding, the greater the R\&D investment.

When the enterprise's exogenous financing is too much, especially exceeds a certain percentage, because of the adverse selection and moral problems arising from the asymmetry of the information, the creditor will develop a detailed and more binding debt contract to supervise and standardize the behavior of using funds borrowed, so as to better ensure that we can get the principal and interest on time. However, it is necessary to require enterprises to maintain the sustainability of $R \& D$ investment due to the needs of market competition and consumer demand for new products and technologies hence the requirement of a great number of financing sources and large financing scale is arising [3]. The hard constraint characteristics of the debt contract actually limit the scale of corporate financing, which may lead to the lack of investment in high and new technology, so that is not conducive to the development of technological innovation, high debt enterprises are also exposed to higher bankruptcy risk. Consequently, enterprises ate generally reluctant to support innovation by increasing debt, but rely more on endogenous financing to support investment with a high degree of uncertainty. Increased investment in innovation will lead to a decline in corporate profits, will also cause individual shareholders to "vote with their feet" to enable enterprises to face the risk of being acquired, so that threaten the safety of senior executives' position and reduce the operator's initiative of technological innovation investment. From the above point of view, we propose Hypothesis 3:

H4: The higher the asset-liability ratio, the smaller the $\mathrm{R} \& \mathrm{D}$ investment of high-tech enterprises.

\section{SAmple SELECTION AND EMPIRICAL ANALYSiS}

\section{A. Sample Selection}

After the implementation of the new accounting standards for listed companies on January 1, 2007, a company's development expenditure become an independent accounting account for non-current assets. Based on the 2015 annual financial statements of listed companies, this paper takes the natural logarithm of published development expenditure as a variable of innovation $R \& D$ investment of high-tech enterprises, and takes the 2010 cross-sectional sample of listed companies of high-tech industry of Shanghai Stock Exchange and Shenzhen Stock Exchange as the research sample. The data comes from the annual report of listed companies published by the database of Tai'an. By sorting out these annual report data, we got the analysis sample. Then this paper regarded A-share listed companies in Shenzhen and Shanghai stock market of our country as the research object. In order to ensure the validity of the data and the accuracy of the study, we exclude the ST and PT companies with extreme values and the companies whose performance appear the abnormal fluctuations and eliminate companies with missing data and financial companies. Finally we get 197 high-tech listed companies in Guangdong.

\section{B. Variable Setting}

\section{1) Dependent variable}

There are more measurement methods for R\&D investment, but the most important is the investment in capital. The investment of funds determines the level of research foundation provided by the whole $R \& D$ project. Relative to the enterprise per capita $R \& D$ costs and the number of enterprise innovation or the number of patents within a certain period, this paper tends to use the ratio of enterprise $R \& D$ investment to sales revenue to measure the intensity of $\mathrm{R} \& \mathrm{D}$ investment.

\section{2) Corporate governance mechanism indicator}

According to the research needs, this paper mainly uses the ownership concentration, the board size and the senior executive incentive to reflect the listed companies' corporate governance level. The ownership concentration is measured by the square sum (Cstr5) of the top 5 shareholders. The board size (B-size) is measured by the natural logarithm of the total number of directors. Executive incentive level (Msr) is measured by the proportion of the top three executives' total holding number in the total number of shares.

\section{3) Control variable}

According to the existing literature, this paper selects the financial leverage (Lever) variable as the control variable.

TABLE I. The MEANing OF VARIABLES

\begin{tabular}{|c|c|l|}
\hline \multirow{2}{*}{ Dependent Variable } & Ratio & $\begin{array}{l}\text { ratio of R\&D } \\
\text { expenditure to sales } \\
\text { revenue }\end{array}$ \\
\hline \multirow{2}{*}{$\begin{array}{c}\text { Explanatory } \\
\text { Variables }\end{array}$} & Cstr5 & $\begin{array}{l}\text { the square sum of the } \\
\text { top 5 shareholders }\end{array}$ \\
\cline { 2 - 3 } & B_Size & $\begin{array}{l}\text { the natural logarithm } \\
\text { of the total number of } \\
\text { directors }\end{array}$ \\
\hline Control Variable & Leverage & $\begin{array}{l}\text { the proportion of the } \\
\text { executives total } \\
\text { holding number in } \\
\text { the total number of } \\
\text { shares }\end{array}$ \\
\hline asset-liability ratio \\
\hline
\end{tabular}




\section{Regression Model}

On the basis of the hypothesis, we construct the regression model of the impact of the corporate governance of the high-tech enterprises on R\&D investment, and use OLS regression analysis method to test this paper's hypothesis:

$$
\begin{aligned}
& \text { Ratio }=\beta_{0}+\beta_{1} \times \text { Cstr5 }+\beta_{2} \times \text { B_Size }+\beta_{3} \times \mathrm{Msr}+\beta_{4} \times \\
& \text { Leverage }+\varepsilon .
\end{aligned}
$$

Where is the intercept, are the coefficients, is the residual.

\section{Empirical results and Analysis on the Impact of Corporate Governance on R\&D Investment in High-tech Enterprises}

Using the above model with the SPSS software processing, we can get the correlation results of the four variables of the high-tech listed companies to Ratio, as shown in Table 2:

TABLE II. THE REGRESSION COEFFICIENT OF THE EXPLANATORY VARIABLES OF THE HIGH-TECH LISTED COMPANIES TO RATIO

\begin{tabular}{|l|l|l|l|l|}
\hline Hypothesis & Variable & $\begin{array}{c}\text { Expected } \\
\text { symbol }\end{array}$ & Coefficient & P-value \\
\hline & $\begin{array}{l}\text { Constant } \\
\text { term }\end{array}$ & & 0.37 & 0.844 \\
\hline H1 & Cstr5 & + & $0.051^{* *}$ & 0.014 \\
\hline H2 & B_Size & + & 0.028 & 0.641 \\
\hline H3 & Msr & + & 0.538 & 0.314 \\
\hline H4 & Leverage & - & -0.016 & 0.825 \\
\hline
\end{tabular}

Note:*, ${ }^{* *}, * * *$ respectively represent the estimated coefficient is significant at the $10 \%, 5 \%, 1 \%$ confidence level.

Table 2 reports the regression coefficient of the variables of the high-tech listed companies to ratio. We find that the ownership concentration is positively related to $R \& D$ investments in the high-tech listed companies. Table 2 shows that the $\mathrm{p}$-value is 0.014 , that the correlation coefficient is low and significant and the coefficient symbols of the other variables are the same as expected. Beyond that other variables and assumptions basically consistent, but the adjusted $\mathrm{R}$ square value is very low, the regression effect is not ideal. It can be seen that the impact of high-tech corporate governance mechanism on $R \& D$ investment is not strong [4]. This is inconsistent with the previous conclusions that the corporate governance of the high-tech enterprises have a significant impact on $R \& D$ activities.

\section{STUdy CONCLUSION}

This paper takes the R\&D investment behavior of hightech enterprises as a research object to conduct a discussion and empirical research from the key characteristics of four corporate governance, such as ownership structure, board size, executive incentive and asset-liability ratio. The empirical results suggest that the ownership concentration has a significant effect on the R\&D investment behavior in the sample range, but the board size has no significant effect on the R\&D investment and technological innovation investment of high-tech enterprises. Compared with other assumptions, although the coefficient of the incentive variables of the senior executive is higher and the expected symbol is the same, the R\&D investment behavior is not significant. This shows that the Guangdong high-tech enterprises need to further improve in the management incentives, so that the development of companies' $R \& D$ activities to be protected and get attention. Only by implementing the targeted system construction, the high-tech enterprises in Guangdong can have a positive impact on $\mathrm{R} \& \mathrm{D}$ investment within the company.

\section{ACKNOWLEDGMENT}

Fund Program: (20160705) (201510010224) and (2015WCXTD005)

\section{REFERENCES}

[1] Chauvin, K., and C. Shenoy, 2001, "Stock Price Decreases Prior to Executive Stock Option Grants", Journal of Corporate Finance, vol.7, pp. 53 76.

[2] Frydman. R. Cheryl, G, Marek, H and Rapaczynski, A. When Does Privatization Work? The Impact of Private Ownership on Corporate Performance in the Transition Economies. Quarterly Journal of Economics, 1999, (114): 1153-1190.

[3] Jensen, M. C. Agency Costs of Free Cash Flow, Corporate Finance, and Takeover. American Economic Reviews, 1986, (76): 323-328.

[4] La Porta. R, Lopez-de-Silanes. F and Shleifer. Corporate Ownership around the World. Journal of Finance, 1999, (54): 471-571.

[5] John E. Tyler III, Advancing University Innovation: More Must Be Expected-More Must Be Done,10 MINN. J.L. SCI. \& TECH. 2009,(143), 189-201 (2009). 